\title{
Can (We Make) Bacillus thuringiensis Crystallize More Than Its Toxins?
}

\author{
Guillaume Tetreau (1), Elena A. Andreeva, Anne-Sophie Banneville, Elke De Zitter and Jacques-Philippe Colletier* \\ Univ. Grenoble Alpes, CNRS, CEA, Institut de Biologie Structurale, F-38000 Grenoble, France; \\ guillaume.tetreau@gmail.com (G.T.); Elena.Andreeva@ibs.fr (E.A.A.); Anne-Sophie.Banneville@ibs.fr (A.-S.B.); \\ Elke.De-Zitter@ibs.fr (E.D.Z.) \\ * Correspondence: colletier@ibs.fr
}

check for

updates

Citation: Tetreau, G.; Andreeva, E.A.; Banneville, A.-S.; De Zitter, E.;

Colletier, J.-P. Can (We Make) Bacillus thuringiensis Crystallize More Than

Its Toxins?. Toxins 2021, 13, 441.

https: / / doi.org/10.3390/

toxins 13070441

Received: 22 May 2021

Accepted: 24 June 2021

Published: 26 June 2021

Publisher's Note: MDPI stays neutral with regard to jurisdictional claims in published maps and institutional affiliations.

\begin{abstract}
The development of finely tuned and reliable crystallization processes to obtain crystalline formulations of proteins has received growing interest from different scientific fields, including toxinology and structural biology, as well as from industry, notably for biotechnological and medical applications. As a natural crystal-making bacterium, Bacillus thuringiensis (Bt) has evolved through millions of years to produce hundreds of highly structurally diverse pesticidal proteins as micrometer-sized crystals. The long-term stability of $B t$ protein crystals in aqueous environments and their specific and controlled dissolution are characteristics that are particularly sought after. In this article, we explore whether the crystallization machinery of $B t$ can be hijacked as a means to produce (micro)crystalline formulations of proteins for three different applications: (i) to develop new bioinsecticidal formulations based on rationally improved crystalline toxins, (ii) to functionalize crystals with specific characteristics for biotechnological and medical applications, and (iii) to produce microcrystals of custom proteins for structural biology. By developing the needs of these different fields to figure out if and how Bt could meet each specific requirement, we discuss the already published and/or patented attempts and provide guidelines for future investigations in some underexplored yet promising domains.
\end{abstract}

Keywords: pore-forming toxin (PFT); pesticidal protein; bacteria; crystals; crystalline formulation; bioinsecticide; biotechnology; structural biology

Key Contribution: Bacillus thuringiensis crystallization machinery can be hijacked to meet the increasing need for custom microcrystals for academic and industrial purposes.

\section{Introduction}

A crystal is a regular tridimensional arrangement of identical molecules or complexes of molecules. As opposed to solutions (liquids) and aggregates (amorphous solids), where molecules are randomly distributed and oriented, a crystal is characterized by a symmetry with a limited number of unique molecule orientations imposed by the crystal lattice [1]. This is associated with a number of properties that are exploited by different scientific fields. For example, the high level of crystal symmetry allows diffracted X-rays to be detected and analyzed to solve the structures of biological macromolecules, a key knowledge to finely understand their function(s). Macromolecular X-ray crystallography (MX) is accordingly the most prolific method in structural biology, accounting for more than $90 \%$ of the structures deposited in the Protein Data Bank (PDB) [2]. Additionnally, crystals represent a means to provide molecules at high concentration and with properties that can be tailored to provide long-term storage, controlled release, and retained activity. This is of particular interest for drug development and delivery, notably of pharmaceuticals [3,4], but also for catalysts that can be formulated for large-scale industrial applications [5,6]. Crystals therefore hold the promise of multiple applications, from the most fundamental academic research purposes 
to the development of innovative biotechnological products [6]. However, the crystallization of macromolecules, and notably proteins, is a process hardly predictable due to the many parameters affecting the nucleation and growth of crystals [7-9]. Crystallization of proteins implies that they are intrinsically capable of sufficiently strong crystal packing interactions to retain order in the long range. Not all proteins are able to form such interactions, and even if they do, the conditions to obtain a crystal are generally highly specific and involve many different parameters. In vitro, crystal formation depends on the purity and concentration of the protein, the nature and concentration of the protein precipitant, the nature of the buffer, the $\mathrm{pH}$, the temperature, etc. [10]. To explore and identify the conditions of crystallization for one particular protein, a classical approach consists of establishing its crystallization phase diagram (Figure 1A) [11]. Different methods of crystallization have been developed in vitro to generate different crystallization trajectories to either favor single macrocrystals or multiple microcrystals [10]. Despite the development of several different crystallization procedures during recent decades [12], the identification and optimization of crystallization conditions leading to a desired set of crystal properties can sometimes be a long and tedious empirical exploration that may be paved paved with failure $[4,5,13]$.


Figure 1. Crystallization requires a protein-specific combination of parameters. (A) The phase diagram represents the protein concentration as a function of the crystallization condition (concentration in precipitant, buffer concentration, etc.). This diagram is adapted from [10]. The concentration of the protein gradually increases to transition from the undersaturated zone (yellow) to the nucleation zone (green) for the crystal to start forming, thereby decreasing the concentration of protein in solution until the limit of protein supersaturation (purple) is reached and the crystal is stably formed (red lines in Figure 1A). Depending on the method used, the starting protein concentration, and the crystallization condition, one can obtain large single crystals (red dotted line) or multiple microcrystals (red solid line). (B) Example of a theoretical shuttle vector that can be used to produce a crystal of toxin in $B t[14,15]$. It contains two origins of replication and two resistance cassettes that allow plasmid construction in one species (Escherichia coli) and toxin crystallization in Bt. The toxin gene expression is controlled by sporulation promoters, and the transcript is stabilized by a Shine-Dalgarno (SD)-like sequence from the $5^{\prime}$ UTR region of the cry3aa gene [16] and by a stem-loop in $3^{\prime}$ UTR [17]. Accessory proteins can be added to facilitate the folding and assembly and/or stabilize crystal contact interactions. More details on the role of these different features are provided in the first article of this back-to-back series and in the following references [18-23].

Protein crystallization is ubiquitous in nature [24]. In vivo crystallization has been known for decades and is notably associated with diseases [25,26], encapsulation [27,28], and storage of nutritive proteins [29,30] and virulence factors [22,31]. In humans, CharcotLeyden crystals, which are composed of the eosinophil galectin-10 protein, are characteristics of allergy-induced asthma [32]. In viviparous cockroaches, mothers feed their offspring with "milk" constituted of crystals of heterogeneous glycosylated proteins [33]. In Baculoviruses, polyhedrin proteins are produced at high concentration during the late stage of insect cell infection to protect the virion by encapsulating it into an intracellular crystal called polyhedral [34]. Using living organisms to produce proteins in the form of 
nano/micrometer-sized crystals directly in cells or cell compartments could be of high interest, notably as it bypasses the need to extract, purify, and crystallize proteins in nonphysiological conditions [35]. The in vivo crystallization of recombinant proteins has already been attempted and observed in plant [36,37], animal [38-40], insect [41-43], and bacterial $[44,45]$ cells. Among all these living organisms able to produce crystals, one is of particular interest, the bacterium Bacillus thuringiensis (Bt).

$B t$ has evolved over millions of years into a natural crystal maker, with hundreds of subspecies each crystallizing one or more toxins. These toxins exhibit drastically different tridimensional structural organization [46] and recognize contrasting protein receptors within the gut of insects from various invertebrate phylogenetic groups. Despite these differences driven by their contrasting modes of action, the pathways of crystallization of each of these toxins lead to crystals with shared characteristics, namely highly intrinsic organization of toxins within the crystal, long-term stability in aqueous environment, and specific dissolution of crystals to alkaline medium. Using $B t$ to produce custom nanocrystals in vivo could therefore be envisioned by capitalizing on the knowledge acquired during the last decades on the mode of action of $B t$ toxins and their mechanisms of crystallization. A variety of tools allowing the genetic manipulation of $B t$, notably including a large set of shuttle vectors (Figure 1B), have been developed to modify $B t$ strains and stably express a large variety of toxins and toxin complexes [14,47]. In addition, several acrystalliferous $B t$ strains, i.e., curated from their plasmids that carry toxin genes, have been developed for the recombinant production of toxin crystals [48-51].

In the present article, we selected three fields for which the combination of the knowledge acquired and the molecular biology tools developed have benefited or could benefit the recombinant production of custom proteins as crystals in Bt. This selection is obviously subjective and is organized from the most studied and referenced domain to the most underexplored, albeit promising, one. Bt crystallization system could be hijacked to develop new bioinsecticidal formulations based on rationally improved crystalline toxins (Section 2), to functionalize crystals with specific characteristics for biotechnological and medical applications (Section 3), and to produce microcrystals of custom proteins for structural biology (Section 4). Each of these three aspects is discussed with regard to the existing literature, if any, and guidelines are provided for promoting further developments in the promising aspects of each field.

\section{Producing New Crystalline Toxins for the Development of Innovative Bioinsecticides}

$B t$ has been increasingly used over the last century for an environmentally friendly integrated pest control strategy [52]. Commercialized biopesticides for topical applications have essentially relied on few approved WT strains with narrow host spectra, namely $B t$ subsp. kurstaki (Btk) and aizawai (Bta) against Lepidoptera, Bt subsp. israelensis (Bti) against Diptera, and Bt subsp. tenebrionis (Btt) against Coleoptera [53,54]. Limited host spectrum is one of the major advantages of $B t$-based bioinsecticides, which allows off-target effects to be limited while reducing the range of pest insects that can be controlled with one given $B t$ subspecies. Different strategies have been published [22,54], patented [55,56], and commercialized $[53,54]$ to bypass these limitations. The rotational or pivotal use of a given $B t$ subspecies with another $B t$ subspecies (or another entomopathogen organism) allows taking advantage of the properties of each toxin mixture. For example, mosquito control can be achieved by combining the Bti's four-toxin mixture with crystals of the binary toxin Tpp1Aa/2Aa (formerly BinAB) produced by the bacterium Lysinibacillus sphaericus $(L s)$. When used together, they reduce the risk of resistance development in mosquito populations and increase the range of mosquito species targeted [57-59]. Further research has been devoted to engineer $B t$ strains, either by conjugation or recombination, with the aim of extending the set of toxins they produce. Tpp1Aa/2Aa toxins were notably introduced in $B t i$ to gain the advantage of the extended toxin mixture while reducing the need for multiple crystal production processes [60]. Similarly, Cry11Ba from Bt subsp. jegathesan (Btj), a homolog of Bti's Cry11Aa that exhibit higher toxicity and an extended 
host spectrum [61], was produced in Bti. By using acrystalliferous strains, such as Bti 4 Q7 [48], novel toxin combinations can be created, for example, concomitantly producing the toxins Cyt1Aa from Bti, Cry11Ba from Btj, and Tpp1Aa/2Aa from Ls [62]. A similar approach was used to generate and commercialize $B t$ strains with a large pest spectrum activity by appending anticoleopteran toxins, such as Cry3Aa from Btt or Cry3Bd from $B t$ subsp. kumamotoensis, to antilepidopteran toxins produced by $B t k$, yielding to the Foil ${ }^{\circledR}$ and Raven ${ }^{\circledR}$ products, respectively [53].

Tailoring of the toxicity level and host range of $B t$ strains can be achieved not only by the discovery of new toxins and by creating $B t$ strains with new toxin combination but also by directly engineering the toxins themselves. The characterization of some aspects of the mode of action of toxins has driven the modification of toxins, in particular to bypass any resistance mechanism developed by insects, especially target site modifications $[63,64]$. For example, Cry1AMod toxins were constructed from either Cry1 Ab or Cry1Ac by removing the helix $\alpha-1$ and part of helix $\alpha-2$ from the $N$-terminal part of proteins [65] based on the observation that Cry1 A binding to a cadherin receptor leads to the cleavage of these residues and increases toxicity [66]. For Cry3Aa, this is the incorporation of chymotrypsin cleavage sites in a loop between the helices $\alpha-3$ and $\alpha-4$ of domain I, which yields the toxin mCry3 $\mathrm{Aa}$, thereby accelerating its activation and leading to an increased toxicity and widened host spectrum [67]. Phylogenetic analyses of the domains from three-domain Cry toxins revealed that part of the toxin evolution leading to the diversity of $B t$ toxins relied on homologous recombination of their domain III, known to be involved in recognition and binding to receptors and in toxin oligomerization [68]. This led to many interchanges between domains III, or part of it, to tailor the toxin toxicity and spectrum. Domain III of Cry3Aa was replaced by that of Cry1 Ab, leading to eCry3.1Ab with improved toxicity to Diabrotica virgifera by targeting different gut receptor(s) [69]. The replacement of domain III of Cry1Ab by that of Cry1F (yielding the new toxin named Cry1A.105 [70]; Figure 2A) or Cry1C, both from Bta, led to a widened host spectrum [71] and increased toxicity against Spodoptera exigua [72], respectively. Similar results against Spodoptera frugiperda were obtained by combining domains I and II of Cry1Ba, domain III of Cry1Ca, and the "crystallization domain" of Cry1Ac [73]. Of note, several of these recombinant/modified toxins have been introduced in genetically modified (GM) plants directly producing the toxins, thereby circumventing several limitations of topical insecticide applications (e.g., limited persistence, difficult timing of applications, and higher production costs) [53]. Cyt1Aa toxin from Bti has also been used to generate chimeras, expanding its host spectrum to other mosquito species when fused to the binary Tpp1Aa/2Aa (formerly BinAB) from Ls [74] and to lepidopteran when the recognition loop 3 of domain II from Cry1 Ab was inserted between its loops 1 and 2 [75]. Interestingly, interdomains exchanges conducted between Cry11Aa and Cry11Ba from Bti and Btj, respectively, highlighted that while some domain combinations improved the mosquitocidal activity, others completely abolished the ability of the chimeras to form inclusions [76,77]. This exemplifies how different domain shuffling using two "sister" toxins, which should crystallize through a similar, albeit thus far uncharacterized, pathway and exhibit alike mode of actions, can alter the formation and stability of their crystal, along with their specificity and toxicity. This provides key information to guide modifications of the properties of both the toxin and its crystal. 
A

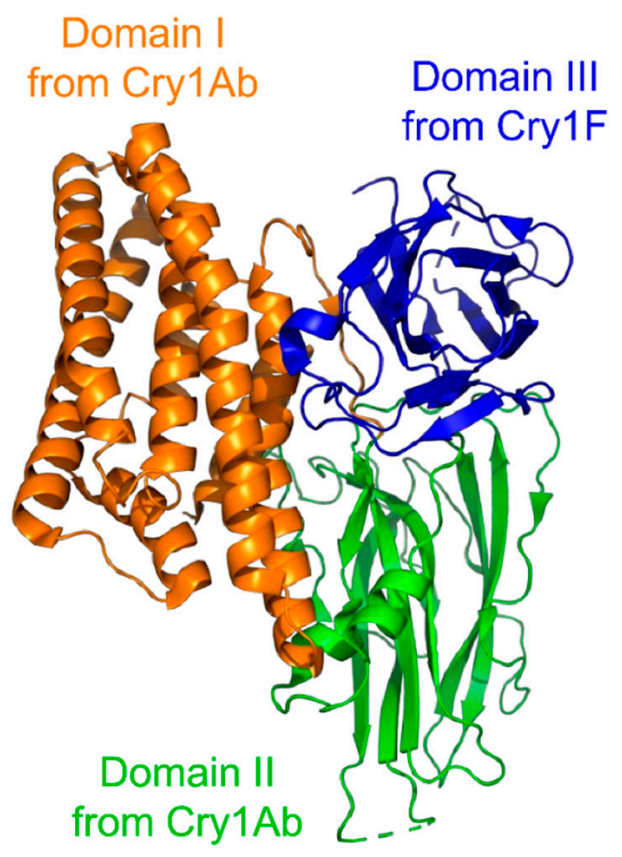

B

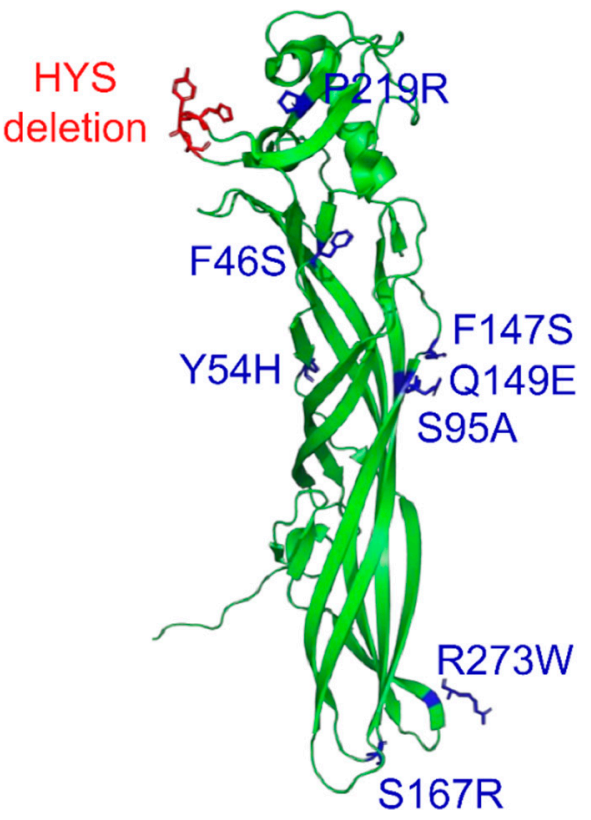

Figure 2. Structures of modified toxins with enhanced activity. (A) Structure of the tryptic core of the modified Cry1A.105 (PDB accession number: 6DJ4) toxin constituting domains I (orange) and II (green) from Cry1Ab and domain III (blue) from Cry1F [70]. (B) Structure of the Mpp51Aa2 toxin (formerly Cry51Aa2; PDB accession number: 5HD2) with eight mutated and three deleted residues to form the modified Cry51Aa2.834_16 toxin, highlighted in blue and green, respectively [78]. The 3D structures are represented in cartoon mode and the mutated residues in licorice mode using PyMOL Molecular Graphics System version 2.4.1.

Of note, fusion of different toxins or toxin parts with non- $B t$ toxic proteins has been performed to combine their insecticidal properties for pest control. For example, Cry1Ac fusion with Av3 toxin from the Cnidaria Anemonia viridis [79], WTX-XI toxin from the spider Ornithoctonus huwena [80], w-ACTX-Hv1 toxin from the spider Hadronyche versuta [81], or chitinases of various origins [82,83] all led to increased toxicity toward lepidopteran species. Although these chimeras generally generated inclusions when produced in $B t$, their crystallinity and overall stability is yet to be demonstrated in order to develop new, reliable bioinsecticidal products. Their ability to form crystals rather than mere inclusion bodies may depend on the toxin but also on the fused protein, and not all combinations may lead to crystalline inclusions. Further studies combining different toxins and cargo proteins with different characteristics (e.g., molecular weight, isoelectric point, hydrophobicity, etc.) should be conducted and complemented by crystallinity investigations using suitable $\mathrm{X}$-ray sources.

Strong phenotypic changes on toxins can also be obtained by a "surgical strike" strategy based on the modification of only few selected amino acids of high importance. Based on this approach, some engineered toxins have been developed, patented, and commercialized, such as Cry1Da_7, a Cry1Da triple mutant (S282V-Y316S-I368P) with >50-fold increased toxicity toward the lepidopteran Helicoverpa zea [73], and Cry51Aa2.834_16, a modified Mpp51Aa (formerly Cry51Aa) toxin containing eight point mutations and three-residue deletion leading to a $>200$ fold increased toxicity to the hemipteran Lygus sp. [78] (Figure 2B). Hundred- to thousand fold increases in mosquitocidal activity could also be obtained by four point mutations in Cry4Ba [84] and by four point mutations combined with a five-residue deletion in Cry19Aa [85]. Structural studies, notably based on X-ray crystallography and modeling, greatly help in identifying key residues to be mutated [86,87]. Moreover, structures solved directly from crystals grown in vivo provide insights into the crystallization pathways to design mutations affecting not only toxin activity and host spectrum but also crystal formation and stability. We recently used the in vivo structure of Cyt1Aa protoxin to show that the size, shape, production 
yield, pH sensitivity, and toxicity of Cyt1Aa crystals grown in Bti could be controlled by single amino acid substitutions [88]. Additional crystallographic studies on crystals grown in vivo are therefore expected to further extend and rationalize the strategy of toxin improvement through point mutations.

\section{Functionalizing Toxin Crystals for the Development of New Biotechnological Tools}

Protein crystals have gained interest in a variety of research domains as their properties, especially their high intrinsic order and porosity, could allow stabilizing functional proteins within the protein crystal scaffold for application in biotechnology and medicine [6]. The possibility of using protein crystals as a polyvalent nanomaterial able to concentrate, stabilize, and protect functional proteins has been envisaged for a large range of applications, notably including biosensing (i.e., detection of relevant molecules by the use of biological macromolecules), biotemplating (i.e., assembly of inorganic nanostructures guided by the protein crystal scaffold), catalysis, and vaccine/drug delivery [3-6]. Extensive engineering efforts have been made by acting on the crystal packing interfaces, notably through cross-linking $[89,90]$, to tailor the crystal properties and create new scaffolds leading to potentially new crystal functionalities but also by finely tuning the pore structure and associated physicochemical characteristics to adjust the properties of the cargo protein [6].

Some $B t$ toxins offer a stable crystalline framework perfected over millions of years of evolution. Using $B t$ toxins crystals to entrap cargo proteins for either of the applications mentioned above could therefore facilitate the production of functional crystalline formulations by direct production in vivo, thereby bypassing the need for laborious protein extraction, purification, and in vitro crystallization. Michael K. Chan's group has provided the most comprehensive investigation to date on this aspect. They published [45,91-95] and patented [96-98] a strategy involving different Cry toxins and more specifically Cry3Aa, which they selected for further investigations for several reasons. Cry3Aa is a toxin with high self-assembly propensity that is able to crystallize both in vitro and in vivo with similar crystal packing interfaces, indicating that its crystallization process is strongly driven by the toxin itself, pending an adequate toxin concentration $[31,99,100]$. Moreover, the checkerboard-like crystal packing of Cry3Aa offers large solvent channels that could be able to accommodate a cargo protein up to $\sim 50 \AA$ in diameter (Figure 3 ) [31,45]. This contrasts with other toxins, such as Cyt1Aa, which pack into crystals that might be too dense to allow a cargo protein to cocrystallize [88], although recent attempts suggest that it might not be an insuperable barrier [74].

Enzymes are increasingly used for industrial applications for biocatalytic processes of high economic importance, in particular for food processing, biofuel production, and natural gas conversion, and strategies to immobilize and boost the efficacy of these catalysts are particularly sought after $[5,101,102]$. For these reasons, research has been performed to provide a proof-of-concept of their approach using lipases from different origins with the aim of developing nanocrystalline formulations of a biocatalyst for the production of biodiesels $[45,92,93]$. It was shown that crystals of Cry3Aa allowed proteins up to 32 $\mathrm{kDa}$ to freely diffuse in the crystal after in vitro coincubation [95]. However, the cargo protein tended to be released from the crystal upon washing with buffer $[93,95]$, suggesting that the protein might not succeed in being deeply buried into the solvent channels of the toxin crystals. This problem was circumvented by performing in vivo entrapment of the cargo protein, either by fusing the protein to the toxin $[45,92,93]$ or by simply coexpressing them during the sporulation of the bacterium [93]. Both strategies revealed that the crystals successfully incorporated the cargo protein at high concentration and that the latter retained its catalytic activity. Moreover, crystals allowed the enzymes to be protected from degradation and to sustain their catalytic activity over several successive cycles of oil-into-biodiesel conversion $[45,92,93]$. They also showed that Cry3Aa toxin could be modified to favor the addressing of the cargo protein to the solvent channel by deleting the last 19 C-terminal amino acids before fusing with the lipase, which led to improved 
catalysis [45], although the yield remained lower than when the lipase was entrapped by simple coexpression with the toxin during Bt sporulation [93]. Altogether, these results highlight the versatility of the Cry3Aa crystallization system to entrap functional catalysts of high economic importance and the possibility to tailor the system for improving the efficacy of both cargo protein entrapment and catalytic activity. Although it is unclear whether all the inclusions that were obtained possessed the intrinsic organization of a crystal, it was shown that they managed to retain a sufficiently high quantity of functional protein for a phenotype to be observed and quantified [93]. This will hopefully fuel further research investigating additional $B t$ toxin/cargo protein combinations to explore the full potential and establish the limits of this system.



Figure 3. Cry3Aa crystal reveals large solvent channels accommodating proteins up to $50 \AA$ in diameter. (A) Crystal packing of Cry3Aa monomers in vivo (PDB accession number: 4QX0). The eight monomers interacting to form the solvent channels are colored in red, blue, green, yellow, orange, cyan, magenta, and wheat tint, while all other monomers are in gray. (B) Zoomed view of the eight monomers with distances of the channel indicated in $\AA$. (C) Structures of three proteins for which cocrystallization with Cry3Aa improved their stability, delivery, and/or activity: the catalytic enzyme Proteus mirabilis lipase (PML) [92], an antimicrobial peptide (dermaseptin) [95], and myoglobin [94] with the PDB accession numbers 4GW3, 2DD6, and 2SPL, respectively. The structures used here are illustrative only and not representative of the exact proteins used in the respective studies. Values indicate the length and width of the three proteins given in $\AA$. The 3D structures from panels A and B are represented in licorice-sticks mode and those in panel C in both licorice-sticks and mesh modes using PyMOL Molecular Graphics System version 2.4.1.

The same group also explored the potential of Cry3Aa crystals for drug delivery [91,94,95]. The use of crystalline formulations for the storage and delivery of biopharmaceutical proteins has received increasing interest during the last decade $[13,103,104]$ as it offers many advantages associated with their higher stability, long-lasting and progressive diffusion within the organism, and long-term storage [3,4]. The major limitations to the widespread use of crystalline formulations is the lack of expertise on large-scale crystallization, the high heterogeneity of crystalline productions, and the absence of simple and straightforward crystal purification methods [3]. In vitro cocrystallization processes have been envisaged, notably for efficient 
drug delivery, but their development is hampered by similar practical limitations $[13,105]$. This explains why the number of crystalline formulations produced and commercialized is still limited [106]. Insulin was the first, and for long time the only, therapeutic protein produced and commercialized in a crystalline formulation [3]. In vivo crystallization, notably using $B t$, could allow an expansion of the set of crystalline biopharmaceuticals in the market. Cry3Aa was shown to successfully entrap antimicrobial peptides and myoglobin, which could be further taken up by macrophages and cancer cells, respectively [94,95]. Moreover, by using only the first domain of Cry3Aa, an important domain for Cry3Aa crystallization in $B t$ [31,107], for fusion with myoglobin, results comparable to those with fusions using the full toxin were obtained, indicating that only some parts of the toxin might be sufficient to stabilize the cargo protein. However, the crystallinity of such inclusion has not been verified, and further experiments are needed to explore its effect on crystal-packing interfaces and inclusion properties.

When it comes to biopharmaceuticals, the crystal carrying the cargo protein must be biocompatible, i.e., innocuous for the receiving organism. Two additional precautions must therefore be taken into account, namely the need for innocuous cocrystallizing toxin and the possibility to get rid of $100 \%$ of the remaining living organisms [6]. For the former, although Bt Cry toxins require specific receptors that are absent from mammals [52] and should therefore be safe for therapeutic applications, they could be engineered by strategic point mutations known to abolish their toxicity while not impeding their crystallinity. This has already been demonstrated for toxins like Cyt1Aa (e.g., mutants V122E [108], K154A [109], or Q168E [88]), Cry1Ac (e.g., A92D, N166D, or L167F [110]), Cry3Aa (e.g., V155F-S156M-S157R [111]), Cry11Aa (e.g., R90E [112], S259A [113], or V262A [114]), and Cry11Ba (e.g., G257A or I263A [115]).

\section{Microcrystallization Platform for Structural Biology}

Protein crystals were discovered by chance more than 150 years ago and initially used for protein purification, but their main contribution to science is concomitant with the advent of X-ray crystallography in the late 1930s for the determination of three-dimensional structures of biological macromolecules [116,117]. The combination of the development of multiple crystallization methods $[9,10,12]$, the implementation of cryogenic solutions limiting the propagation of X-ray-induced radiation damage [118], and the easy access to finely tuned and reliable X-ray synchrotron sources has allowed over 130,000 protein structures to be solved over the last 20 years [2]. It is therefore a method of choice for the determination of protein structures at high resolution. In synchrotron facilities, diffraction data are generally collected from a single oscillating macrocrystal $(10-100 \mu \mathrm{m})$ to collect a complete dataset for reconstructing structures. Unfortunately, fragile macromolecules of complex architecture, such as membrane proteins or large protein complexes, and most proteins crystallized by living organisms generally form nano- to micrometer-sized crystals that are not amenable to structure determination by conventional oscillation methods at synchrotron sources. This is notably due to the progression of X-ray-induced radiation damage that is only delayed and not eliminated by flash-cooling (i.e., cryogenic conditions where the crystal is quickly frozen and maintained at a temperature of $\sim 100 \mathrm{~K})$. In practice, this means that the smaller the crystals, the more radiation sensitive they are and the more crystals are required to obtain a radiation-damage-free dataset $[119,120]$. The development of serial crystallography and the advent of X-ray free-electron lasers (XFEL) allowed this limitation to be bypassed. XFELs deliver the same amount of photons as synchrotrons but within tens of femtoseconds versus few milliseconds for the latter, allowing the collection of high-resolution diffraction patterns at room temperature (RT) before radiation damage onset via the so-called "diffraction before destruction" approach [121]. The most immediate consequence is that each crystal only contributes a unique diffraction pattern before it is destroyed by the X-ray beam, so thousands of homogenous microcrystals are required to be injected serially to collect a sufficient number of indexed patterns from different microcrystals in different orientations to determine the protein structure (Figure 4) [122,123]. 


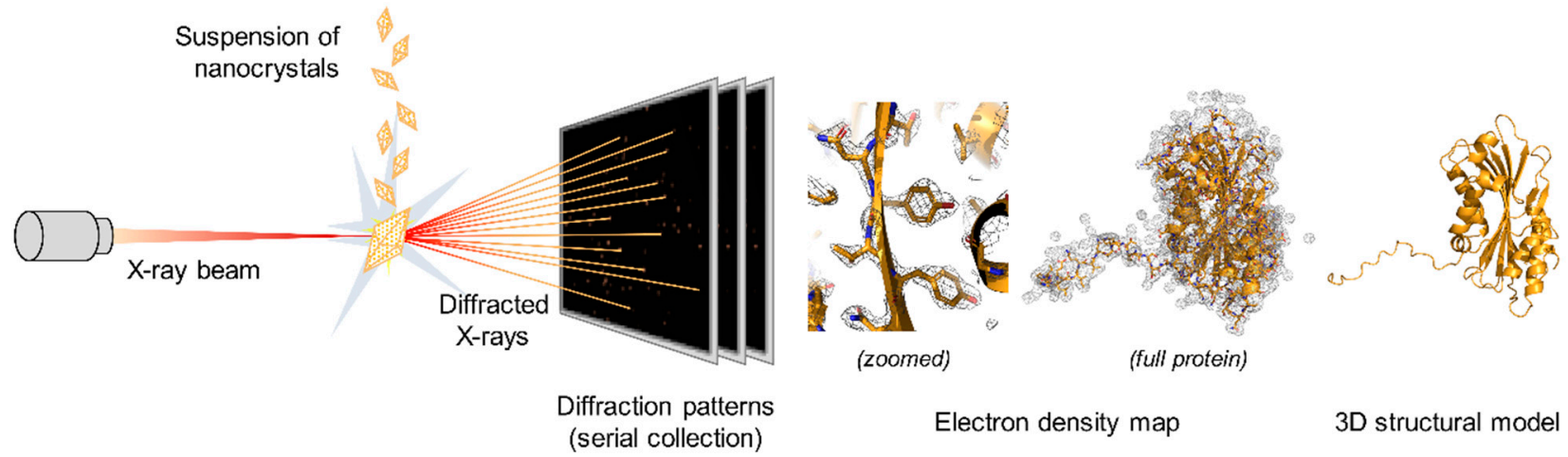

Figure 4. Principle of serial macromolecular X-ray crystallography. A suspension of homogenous crystals is injected serially in the course of an X-ray beam. Each crystal stands still and in random orientations during the exposure, enabling collection of only partial measurements of diffracted intensities. Partial intensities from thousands of indexed patterns from different microcrystals are then merged to generate a dataset that can be analyzed to generate the electron density map and allow determination of the three-dimensional structure of the protein. The 3D structures were generated using PyMOL Molecular Graphics System version 2.1.1 using the structure of Cyt1Aa protoxin with the PDB accession number 6T14 [88].

Several in vitro crystallization procedures have been developed to produce the high quantity of diffraction-grade microcrystals required for such an approach [10]. However, establishing reliable and reproducible procedures remains a laborious process that is very demanding in term of manpower and time and has an unpredictable outcome [7-9,12]. In vivo crystallization has recently emerged as a sound alternative to produce the crystalline samples required for such experiments [24,35,124]. In addition to facilitating crystal production and purification, it would also permit the characterization of crystalline proteins as they naturally occur in the cellular context, i.e., protected from oxidative stress and sometimes in the presence of propeptides before protein maturation $[31,44,88,125]$, and/or in complex with natural ligands subselected from the cytosolic pool of substrate [40,126]. The use of animal and insect cells has been proposed for the further development of in vivo crystallization [42, 127], but major limitations hinder its establishment as a reliable platform for the production and isolation of pure nano/microcrystals. These include (i) cell death upon crystallization, thus raising the question of whether the crystalline protein could suffer oxidative stress and if complexed ligands are selected from the large pool of cytosolic metabolites present in a healthy cell or from the leftovers found in a dying cell [125]; (ii) the production of generally fragile needle-like crystals that are difficult to extract and are unstable outside the cell $[40,124,125]$; and (iii) a serendipitous, unnatural pathway of crystallization, offering little command on crystal size and diffraction quality, thereby limiting the possibility to learn how to engineer self-crystallizing interfaces in vivo from observations made at crystal packing interfaces. In contrast, $B t$ is a natural nanocrystal maker for a large array of proteins with contrasting size and structures, which it can crystallize through finely regulated crystallization pathways $[46,128,129]$. Moreover, it has been shown that high-resolution structures of toxins recombinantly expressed in an acrystalliferous $B t$ strain could be solved from diffraction datasets collected at XFELs directly from crystal-containing $B t$ cells [31] as well as from purified crystals $[31,44,88]$. The knowledge acquired and the molecular tools developed for Bt combined with the multiple successes in using $B t$ toxins as crystallization vessels for cargo proteins (see Sections 2 and 3) point to $B t$ as a model of choice for the in vivo crystallization of recombinant proteins. Of note, the absence of electron density from synchrotron data obtained using Cry3Aa crystals that incorporated a lipase during their growth in vitro [93] suggests that extensive efforts must be done to stabilize the interactions between the crystalline toxin and the cargo protein within the solvent channel. This will require fine-tuning of the sequence and characteristics of the toxin and/or cargo protein to stabilize the protein within the solvent channel while preventing the motions within the cargo protein from becoming restrained should one want to elucidate the dynamic aspects of its function $[130,131]$. Exploring new microcrystallization methods is of utmost interest considering the recent development of 
new solutions for structural biology. The increasing number of beamlines dedicated to serial injection at synchrotron facilities and the progressive upgrade of these $X$-ray sources, which has increased their brilliance by approximately two orders of magnitude to make them so-called extremely brilliant sources (EBS) [132], are opening new opportunities in structural biology. Altogether, they hold the promise to significantly increase the set of biological systems to be investigated by $\mathrm{X}$-ray crystallography and electron microscopy and to enable access to structural information to a wider range of scientists from various disciplinary fields.

\section{Conclusions}

The ability of natural $B t$ strains to make crystals of toxins has been largely exploited for the development of biological insecticide formulations for an integrated pest control strategy. In this article, we covered various successful and failed attempts aimed at hijacking the crystallization machinery of $B t$ for it to be used as a custom crystal biofactory. We saw that bioinsecticide improvement has already been successfully performed by the rationale modification of toxins, thus generating crystals of new toxins with finely tuned properties, and that structural information, especially that obtained directly from crystals grown in vivo, is opening new routes of improvement. Moreover, recent works have highlight that $B t$ toxin crystals could entrap functional cargo proteins of high biotechnological and medical interest, calling for future investigations of additional crystalline toxin/cargo protein combinations to provide a comprehensive overview of the application boundaries of this system. Further studies are expected to explore the means to stabilize the cargo protein within different toxin-driven crystal lattices to tailor their function and to extend their use for structural biology, notably through X-ray crystallography.

Funding: This work was supported by the Agence Nationale de la Recherche (grants ANR-17-CE110018-01 and ANR-2018-CE11-0005-02 to J.-P.C.) and the Grenoble Alliance for Integrated Structural Cell Biology (GRAL) (C7H-LXG11A20-COLLETIER to J.-P.C.).

Institutional Review Board Statement: Not applicable.

Informed Consent Statement: Not applicable.

Data Availability Statement: Not applicable.

Acknowledgments: We would like to thank Colin Berry, Neil Crickmore, Brian Federici, Aurélie Gauthier, Morgane Tetreau, and the Bacteria Division of the "Society for Invertebrate Pathology" at large for fruitful discussions and constructive comments directly and/or indirectly related to the review articles in this series.

Conflicts of Interest: We declare no conflict of interest.

\section{References}

1. Malgrange, C.; Ricolleau, C.; Schlenker, M. Symmetry and Physical Properties of Crystals; Springer: Dordrecht, The Netherlands, 2014; p. 522. [CrossRef]

2. Thompson, M.C.; Yeates, T.O.; Rodriguez, J.A. Advances in methods for atomic resolution macromolecular structure determination. F1000Research 2020, 9, 667. [CrossRef]

3. Basu, S.K.; Govardhan, C.P.; Jung, C.W.; Margolin, A.L. Protein crystals for the delivery of biopharmaceuticals. Expert Opin. Biol. Ther. 2004, 4, 301-317. [CrossRef] [PubMed]

4. Wu, C.; Chen, Z.; Hu, Y.; Rao, Z.; Wu, W.; Yang, Z. Nanocrystals: The preparation, precise control and application toward the pharmaceutics and food industry. Curr. Pharm. Des. 2018, 24, 2425-2431. [CrossRef] [PubMed]

5. Rimer, J.D.; Chawla, A.; Le, T.T. Crystal Engineering for catalysis. Annu. Rev. Chem. Biomol. Eng. 2018, 9, 283-309. [CrossRef] [PubMed]

6. Hartje, L.F.; Snow, C.D. Protein crystal based materials for nanoscale applications in medicine and biotechnology. Wiley Interdiscip. Rev. Nanomed. Nanobiotechnol. 2018, 11, e1547. [CrossRef] [PubMed]

7. Sánchez-Puig, N.; Sauter, C.; Lorber, B.; Giegé, R.; Moreno, A. Predicting protein crystallizability and nucleation. Protein Pept. Lett. 2012, 19, 725-731. [CrossRef]

8. Smialowski, P.; Wong, P. Protein crystallizability. Methods Mol. Biol. 2016, 1415, 341-370. [CrossRef]

9. McPherson, A. Crystallization of Biological Macromolecules; Cold Spring Harbor Laboratory Press: New York, NY, USA, $1999 ;$ p. 586. 
10. Beale, J.H.; Bolton, R.; Marshall, S.A.; Beale, E.V.; Carr, S.B.; Ebrahim, A.; Moreno-Chicano, T.; Hough, M.A.; Worrall, J.A.R.; Tews, I.; et al. Successful sample preparation for serial crystallography experiments. J. Appl. Crystallogr. 2019, 52, 1385-1396. [CrossRef] [PubMed]

11. Ducruix, A.; Giegé, R. Crystallization of Nucleic Acids and Proteins: A Practical Approach; IRL Press at Oxford University Press: Oxford, UK, 1992; p. 331.

12. Gavira, J.A. Current trends in protein crystallization. Arch. Biochem. Biophys. 2016, 602, 3-11. [CrossRef]

13. Desai, P.P.; Mapara, S.S.; Patravale, V.B. Crystal engineering: Upcoming paradigm for efficacious pulmonary drug delivery. Curr. Pharm. Des. 2018, 24, 2438-2455. [CrossRef]

14. Arantes, O.; Lereclus, D. Construction of cloning vectors for Bacillus thuringiensis. Gene 1991, 108, 115-119. [CrossRef]

15. Federici, B.A.; Park, H.-W.; Bideshi, D.K. Overview of the basic biology of bacillus thuringiensis with emphasis on genetic engineering of bacterial larvicides for mosquito control. Open Toxinol. J. 2010, 3, 83-100. [CrossRef]

16. Agaisse, H.; Lereclus, D. STAB-SD: A shine-dalgarno sequence in the $5^{\prime}$ untranslated region is a determinant of mRNA stability. Mol. Microbiol. 1996, 20, 633-643. [CrossRef]

17. Sakano, Y.; Park, H.W.; Bideshi, D.K.; Ge, B.; Federici, B.A. Contributions of $5^{\prime}$-UTR and $3^{\prime}$-UTR cis elements to Cyt1Aa synthesis in Bacillus thuringiensis subsp. israelensis. J. Invertebr. Pathol. 2017, 149, 66-75. [CrossRef] [PubMed]

18. Adalat, R.; Saleem, F.; Crickmore, N.; Naz, S.; Shakoori, A.R. In vivo crystallization of three-domain cry toxins. Toxins 2017, $9,80$. [CrossRef]

19. Agaisse, H.; Lereclus, D. How does Bacillus thuringiensis produce so much insecticidal crystal protein? J. Bacteriol. 1995, 177, 6027-6032. [CrossRef]

20. Deng, C.; Peng, Q.; Song, F.; Lereclus, D. Regulation of cry gene expression in Bacillus thuringiensis. Toxins 2014, 6, 2194-2209. [CrossRef]

21. Schnepf, E.; Crickmore, N.; Van Rie, J.; Lereclus, D.; Baum, J.; Feitelson, J.; Zeigler, D.R.; Dean, D.H. Bacillus thuringiensis and its pesticidal crystal proteins. Microbiol. Mol. Biol. Rev. 1998, 62, 775-806. [CrossRef] [PubMed]

22. Federici, B.A.; Park, H.-W.; Sakano, Y. Insecticidal protein crystals of bacillus thuringiensis. In Inclusions in Prokaryotes; Shively, J.M., Ed.; Springer: Berlin/Heidelberg, Germany, 2006; pp. 195-236. [CrossRef]

23. Lereclus, D.; Agaisse, H.; Grandvalet, C.; Salamitou, S.; Gominet, M. Regulation of toxin and virulence gene transcription in Bacillus thuringiensis. Int. J. Med. Microbiol. 2000, 290, 295-299. [CrossRef]

24. Doye, J.; Poon, W. Protein crystallization in vivo. Curr. Opin. Colloid Interface Sci. 2006, 11, 40-46. [CrossRef]

25. Weller, P.F.; Bach, D.S.; Austen, K.F. Biochemical characterization of human eosinophil charcot-leyden crystal protein (lysophospholipase). J. Biol. Chem. 1984, 259, 15100-15105. [CrossRef]

26. Farrants, G.W.; Hovmöller, S.; Stadhouders, A.M. Two types of mitochondrial crystals in diseased human skeletal muscle fibers. Muscle Nerve 1988, 11, 45-55. [CrossRef]

27. Takemoto, Y.; Mitsuhashi, W.; Murakami, R.; Konishi, H.; Miyamoto, K. The N-terminal region of an entomopoxvirus fusolin is essential for the enhancement of peroral infection, whereas the C-terminal region is eliminated in digestive juice. J. Virol. 2008, 82, 12406-12415. [CrossRef]

28. Sleytr, U.B.; Schuster, B.; Egelseer, E.-M.; Pum, D. S-layers: Principles and applications. FEMS Microbiol. Rev. 2014, 38, 823-864. [CrossRef]

29. Lange, R.H.; Grodziński, Z.; Kilarski, W. Yolk-platelet crystals in three ancient bony fishes: Polypterus bichir (polypteri), amia calva 1., and lepisosteus osseus (1.) (holostei). Cell Tissue Res. 1982, 222, 159-165. [CrossRef]

30. Colman, P.M.; Suzuki, E.; Van Donkelaar, A. The structure of cucurbitin: Subunit symmetry and organization in situ. Eur. J. Biochem. 1980, 103, 585-588. [CrossRef] [PubMed]

31. Sawaya, M.R.; Cascio, D.; Gingery, M.; Rodriguez, J.; Goldschmidt, L.; Colletier, J.-P.; Messerschmidt, M.M.; Boutet, S.; Koglin, J.E.; Williams, G.J.; et al. Protein crystal structure obtained at $2.9 \AA$ resolution from injecting bacterial cells into an X-ray free-electron laser beam. Proc. Natl. Acad. Sci. USA 2014, 111, 12769-12774. [CrossRef] [PubMed]

32. Allen, J.E.; Sutherland, T.E. Crystal-clear treatment for allergic disease. Science 2019, 364, 738-739. [CrossRef] [PubMed]

33. Banerjee, S.; Coussens, N.P.; Gallat, F.X.; Sathyanarayanan, N.; Srikanth, J.; Yagi, K.J.; Gray, J.S.; Tobe, S.S.; Stay, B.; Chavas, L.M.; et al. Structure of a heterogeneous, glycosylated, lipid-bound, in vivo-grown protein crystal at atomic resolution from the viviparous cockroach Diploptera punctata. IUCrJ 2016, 3, 282-293. [CrossRef]

34. Coulibaly, F.; Chiu, E.; Gutmann, S.; Rajendran, C.; Haebel, P.W.; Ikeda, K.; Mori, H.; Ward, V.K.; Schulze-Briese, C.; Metcalf, P. The atomic structure of baculovirus polyhedra reveals the independent emergence of infectious crystals in DNA and RNA viruses. Proc. Natl. Acad. Sci. USA 2009, 106, 22205-22210. [CrossRef] [PubMed]

35. Schonherr, R.; Rudolph, J.M.; Redecke, L. Protein crystallization in living cells. Biol. Chem. 2018, 399, 751-772. [CrossRef]

36. De Cosa, B.; Moar, W.; Lee, S.B.; Miller, M.; Daniell, H. Overexpression of the Bt cry2Aa2 operon in chloroplasts leads to formation of insecticidal crystals. Nat. Biotechnol. 2001, 19, 71-74. [CrossRef] [PubMed]

37. Stöger, E.; Parker, M.; Christou, P.; Casey, R. Pea legumin overexpressed in wheat endosperm assembles into an ordered paracrystalline matrix. Plant Physiol. 2001, 125, 1732-1742. [CrossRef]

38. Hasegawa, H.; Wendling, J.; He, F.; Trilisky, E.; Stevenson, R.; Franey, H.; Kinderman, F.; Li, G.; Piedmonte, D.M.; Osslund, T.; et al. In vivo crystallization of human IgG in the endoplasmic reticulum of engineered Chinese hamster ovary (CHO) cells. J. Biol. Chem. 2011, 286, 19917-19931. [CrossRef] [PubMed] 
39. Gallat, F.X.; Matsugaki, N.; Coussens, N.P.; Yagi, K.J.; Boudes, M.; Higashi, T.; Tsuji, D.; Tatano, Y.; Suzuki, M.; Mizohata, E.; et al. In vivo crystallography at X-ray free-electron lasers: The next generation of structural biology? Philosophical transactions of the Royal Society of London. Ser. B Biol. Sci. 2014, 369, 20130497. [CrossRef] [PubMed]

40. Baskaran, Y.; Ang, K.C.; Anekal, P.V.; Chan, W.L.; Grimes, J.M.; Manser, E.; Robinson, R.C. An in cellulo-derived structure of PAK4 in complex with its inhibitor Inka1. Nat. Commun. 2015, 6, 8681. [CrossRef]

41. Ji, X.; Axford, D.; Owen, R.; Evans, G.; Ginn, H.M.; Sutton, G.; Stuart, D.I. Polyhedra structures and the evolution of the insect viruses. J. Struct. Biol. 2015, 192, 88-99. [CrossRef] [PubMed]

42. Boudes, M.; Garriga, D.; Fryga, A.; Caradoc-Davies, T.; Coulibaly, F. A pipeline for structure determination of in vivo-grown crystals using in cellulo diffraction. Acta Crystallogr. Sect. D Struct. Biol. 2016, 72, 576-585. [CrossRef] [PubMed]

43. Schönherr, R.; Klinge, M.; Rudolph, J.M.; Fita, K.; Rehders, D.; Lübber, F.; Schneegans, S.; Majoul, I.V.; Duszenko, M.; Betzel, C.; et al. Real-time investigation of dynamic protein crystallization in living cells. Struct. Dyn. 2015, 2, 041712. [CrossRef]

44. Colletier, J.P.; Sawaya, M.R.; Gingery, M.; Rodriguez, J.A.; Cascio, D.; Brewster, A.S.; Michels-Clark, T.; Hice, R.H.; Coquelle, N.; Boutet, S.; et al. De novo phasing with X-ray laser reveals mosquito larvicide BinAB structure. Nature 2016, 539, 43-47. [CrossRef] [PubMed]

45. Heater, B.S.; Lee, M.M.; Chan, M.K. Direct production of a genetically-encoded immobilized biodiesel catalyst. Sci. Rep. 2018, 8, 12783. [CrossRef]

46. Berry, C.; Crickmore, N. Structural classification of insecticidal proteins-Towards an in silico characterisation of novel toxins. J. Invertebr. Pathol. 2017, 142, 16-22. [CrossRef]

47. Sansinenea, E.; Vázquez, C.; Ortiz, A. Genetic manipulation in Bacillus thuringiensis for strain improvement. Biotechnol. Lett. 2010, 32, 1549-1557. [CrossRef] [PubMed]

48. Clark, B.D. Characterization of Plasmids from Bacillus Thuringiensis Var. Israelensis; The Ohio State University: Ann Arbor, MI, USA, 1987.

49. Li, L.; Yang, C.; Liu, Z.; Li, F.; Yu, Z. Screening of acrystalliferous mutants from Bacillus thuringiensis and their transformation properties. Wei Sheng Wu Xue Bao Acta Microbiol. Sin. 2000, 40, 85-90.

50. Ji, F.; Zhu, Y.; Ju, S.; Zhang, R.; Yu, Z.; Sun, M. Promoters of crystal protein genes do not control crystal formation inside exosporium of Bacillus thuringiensis ssp. finitimus strain YBT-020. FEMS Microbiol. Lett. 2009, 300, 11-17. [CrossRef] [PubMed]

51. Lereclus, D.; Arantès, O.; Chaufaux, J.; Lecadet, M. Transformation and expression of a cloned delta-endotoxin gene in Bacillus thuringiensis. FEMS Microbiol. Lett. 1989, 51, 211-217. [CrossRef]

52. Raymond, B.; Federici, B.A. In defense of Bacillus thuringiensis, the safest and most successful microbial insecticide available to humanity-A response to EFSA. FEMS Microbiol. Ecol. 2017, 93. [CrossRef]

53. Sanahuja, G.; Banakar, R.; Twyman, R.M.; Capell, T.; Christou, P. Bacillus thuringiensis: A century of research, development and commercial applications. Plant Biotechnol. J. 2011, 9, 283-300. [CrossRef] [PubMed]

54. Kaur, S. Molecular approaches towards development of novel Bacillus thuringiensis biopesticides. World J. Microbiol. Biotechnol. 2000, 16, 781-793. [CrossRef]

55. Shu, C.; Zhang, J. Current patents related to bacillus thuringiensis insecticidal crystal proteins. Recent Pat. DNA Gene Seq. 2009, 3, 26-28. [CrossRef]

56. Swamy, H.M.; Asokan, R.; Rajasekaran, P.E.; Mahmood, R.; Nagesha, S.N.; Arora, D.K. Analysis of opportunities and challenges in patenting of Bacillus thuringiensis insecticidal crystal protein genes. Recent Pat. DNA Gene Seq. 2012, 6, 64-71. [CrossRef] [PubMed]

57. Wirth, M.C.; Jiannino, J.A.; Federici, B.A.; Walton, W.E. Synergy between toxins of Bacillus thuringiensis subsp israelensis and Bacillus sphaericus. J. Med. Entomol. 2004, 41, 935-941. [CrossRef]

58. Wirth, M.C.; Walton, W.E.; Federici, B.A. Evolution of resistance to the Bacillus sphaericus Bin toxin is phenotypically masked by combination with the mosquitocidal proteins of Bacillus thuringiensis subspecies israelensis. Environ. Microbiol. 2010, 12, 1154-1160. [CrossRef]

59. Zahiri, N.S.; Federici, B.A.; Mulla, M.S. Laboratory and simulated field evaluation of a new recombinant of Bacillus thuringiensis ssp israelensis and Bacillus sphaericus against Culex mosquito larvae (diptera: Culicidae). J. Med. Entomol. 2004, 41, 423-429. [CrossRef] [PubMed]

60. Federici, B.A.; Park, H.W.; Bideshi, D.K.; Wirth, M.C.; Johnson, J.J. Recombinant bacteria for mosquito control. J. Exp. Biol. 2003, 206, 3877-3885. [CrossRef]

61. Park, H.W.; Delecluse, A.; Federici, B.A. Construction and characterization of a recombinant Bacillus thuringiensis subsp israelensis strain that produces Cry11B. J. Invertebr. Pathol. 2001, 78, 37-44. [CrossRef]

62. Park, H.W.; Bideshi, D.K.; Federici, B.A. Recombinant strain of Bacillus thuringiensis producing Cyt1A, Cry11B, and the Bacillus sphaericus binary toxin. Appl. Environ. Microbiol. 2003, 69, 1331-1334. [CrossRef]

63. Bravo, A.; Soberon, M. How to cope with insect resistance to Bt toxins? Trends Biotechnol. 2008, 26, 573-579. [CrossRef] [PubMed]

64. Tabashnik, B.E.; Huang, F.N.; Ghimire, M.N.; Leonard, B.R.; Siegfried, B.D.; Rangasamy, M.; Yang, Y.J.; Wu, Y.D.; Gahan, L.J.; Heckel, D.G.; et al. Efficacy of genetically modified Bt toxins against insects with different genetic mechanisms of resistance. Nat. Biotechnol. 2011, 29, 1128-1131. [CrossRef] [PubMed]

65. Soberon, M.; Pardo-Lopez, L.; Lopez, I.; Gomez, I.; Tabashnik, B.E.; Bravo, A. Engineering modified Bt toxins to counter insect resistance. Science 2007, 318, 1640-1642. [CrossRef] [PubMed] 
66. Gomez, I.; Sanchez, J.; Miranda, R.; Bravo, A.; Soberon, M. Cadherin-like receptor binding facilitates proteolytic cleavage of helix alpha-1 in domain I and oligomer pre-pore formation of Bacillus thuringiensis Cry1Ab toxin. FEBS Lett. 2002, 513, 242-246. [CrossRef]

67. Walters, F.S.; Stacy, C.M.; Lee, M.K.; Palekar, N.; Chen, J.S. An engineered chymotrypsin/cathepsin G site in domain I renders Bacillus thuringiensis Cry3A active against western corn rootworm larvae. Appl. Environ. Microbiol. 2008, 74, 367-374. [CrossRef]

68. de Maagd, R.A.; Bravo, A.; Crickmore, N. How Bacillus thuringiensis has evolved specific toxins to colonize the insect world. Trends Genet. 2001, 17, 193-199. [CrossRef]

69. Walters, F.S.; deFontes, C.M.; Hart, H.; Warren, G.W.; Chen, J.S. Lepidopteran-active variable-region sequence imparts coleopteran activity in eCry3.1Ab, an engineered Bacillus thuringiensis hybrid insecticidal protein. Appl. Environ. Microbiol. 2010, 76, 3082-3088. [CrossRef] [PubMed]

70. Wang, C.; Li, W.; Kessenich, C.R.; Petrick, J.S.; Rydel, T.J.; Sturman, E.J.; Lee, T.C.; Glenn, K.C.; Edrington, T.C. Safety of the Bacillus thuringiensis-derived Cry1A.105 protein: Evidence that domain exchange preserves mode of action and safety. Regul. Toxicol. Pharmacol. 2018, 99, 50-60. [CrossRef]

71. Hernandez-Rodriguez, C.S.; Hernandez-Martinez, P.; Van Rie, J.; Escriche, B.; Ferre, J. Shared Midgut Binding Sites for Cry1A.105, Cry1Aa, Cry1Ab, Cry1Ac and Cry1Fa Proteins from Bacillus thuringiensis in Two Important Corn Pests, Ostrinia nubilalis and Spodoptera frugiperda. PLoS ONE 2013, 8, e68164. [CrossRef] [PubMed]

72. de Maagd, R.A.; Kwa, M.S.; van der Klei, H.; Yamamoto, T.; Schipper, B.; Vlak, J.M.; Stiekema, W.J.; Bosch, D. Domain III substitution in Bacillus thuringiensis delta-endotoxin CryIA(b) results in superior toxicity for Spodoptera exigua and altered membrane protein recognition. Appl. Environ. Microbiol. 1996, 62, 1537-1543. [CrossRef] [PubMed]

73. Wang, Y.; Wang, J.; Fu, X.; Nageotte, J.R.; Silverman, J.; Bretsnyder, E.C.; Chen, D.; Rydel, T.J.; Bean, G.J.; Li, K.S.; et al. Bacillus thuringiensis Cry1Da_7 and Cry1B.868 Protein Interactions with Novel Receptors Allow Control of Resistant Fall Armyworms, Spodoptera frugiperda (J.E. Smith). Appl. Environ. Microbiol. 2019, 85, e00579-19. [CrossRef]

74. Bideshi, D.K.; Park, H.-W.; Hice, R.H.; Wirth, M.C.; Federici, B.A. Highly Effective Broad Spectrum Chimeric Larvicide That Targets Vector Mosquitoes Using a Lipophilic Protein. Sci. Rep. 2017, 7, 11282. [CrossRef]

75. Torres-Quintero, M.-C.; Gómez, I.; Pacheco, S.; Sánchez, J.; Flores, H.; Osuna, J.; Mendoza, G.; Soberón, M.; Bravo, A. Engineering Bacillus thuringiensis Cyt1Aa toxin specificity from dipteran to lepidopteran toxicity. Sci. Rep. 2018, 8, 4989. [CrossRef] [PubMed]

76. Florez, A.M.; Suarez-Barrera, M.O.; Morales, G.M.; Rivera, K.V.; Orduz, S.; Ochoa, R.; Guerra, D.; Muskus, C. Toxic Activity, Molecular Modeling and Docking Simulations of Bacillus thuringiensis Cry11 Toxin Variants Obtained via DNA Shuffling. Front. Microbiol. 2018, 9, 2461. [CrossRef] [PubMed]

77. Sun, Y.; Zhao, Q.; Zheng, D.; Ding, X.; Wang, J.; Hu, Q.; Yuan, Z.; Park, H.-W.; Xia, L. Construction and characterization of the interdomain chimeras using Cry11Aa and Cry11Ba from Bacillus thuringiensis and identification of a possible novel toxic chimera. Biotechnol. Lett. 2013, 36, 105-111. [CrossRef]

78. Gowda, A.; Rydel, T.J.; Wollacott, A.M.; Brown, R.S.; Akbar, W.; Clark, T.L.; Flasinski, S.; Nageotte, J.R.; Read, A.C.; Shi, X.; et al. A transgenic approach for controlling Lygus in cotton. Nat. Commun. 2016, 7, 12213. [CrossRef] [PubMed]

79. Ye, X.-L.; Xia, L.-Q. Polyhedrosis Virus in Bacillus thuringiensis. Agric. Sci. China 2011, 10, 92-100. [CrossRef]

80. Sun, Y.; Fu, Z.; He, X.; Yuan, C.; Ding, X.; Xia, L. Enhancement of Bacillus thuringiensis insecticidal activity by combining Cry1Ac and bi-functional toxin HWTX-XI from spider. J. Invertebr. Pathol. 2016, 135, 60-62. [CrossRef]

81. Li, W.P.; Xia, L.Q.; Ding, X.Z.; Lv, Y.; Luo, Y.S.; Hu, S.B.; Yin, J.; Yan, F. Expression and characterization of a recombinant Cry1Ac crystal protein fused with an insect-specific neurotoxin $\omega$-ACTX-Hv1a in Bacillus thuringiensis. Gene 2012, 498, 323-327. [CrossRef]

82. González-Ponce, K.S.; Casados-Vázquez, L.E.; Salcedo-Hernández, R.; Bideshi, D.K.; Del Rincón-Castro, M.C.; Barboza-Corona, J.E. Recombinant Bacillus thuringiensis subsp. kurstaki HD73 strain that synthesizes Cry1Ac and chimeric ChiA74 $\Delta$ sp chitinase inclusions. Arch. Microbiol. 2017, 199, 627-633. [CrossRef] [PubMed]

83. Ding, X.; Luo, Z.; Xia, L.; Gao, B.; Sun, Y.; Zhang, Y. Improving the Insecticidal Activity by Expression of a Recombinant cry1Ac Gene with Chitinase-Encoding Gene in Acrystalliferous Bacillus thuringiensis. Curr. Microbiol. 2008, 56, 442-446. [CrossRef]

84. Abdullah, M.A.F.; Alzate, O.; Mohammad, M.; McNall, R.J.; Adang, M.J.; Dean, D.H. Introduction of Culex Toxicity into Bacillus thuringiensis Cry4Ba by Protein Engineering. Appl. Environ. Microbiol. 2003, 69, 5343-5353. [CrossRef]

85. Abdullah, M.A.F.; Dean, D.H. Enhancement of cry19aa mosquitocidal activity against aedes aegypti by mutations in the putative loop regions of domain II. Appl. Environ. Microbiol. 2004, 70, 3769. [CrossRef]

86. Pinzón-Reyes, E.H.; Sierra-Bueno, D.A.; Suarez-Barrera, M.O.; Rueda-Forero, N.J.; Abaunza-Villamizar, S.; Rondón-Villareal, P. Generation of cry11 variants of bacillus thuringiensis by heuristic computational modeling. Evol. Bioinform. Online 2020, 16, 1176934320924681. [CrossRef]

87. Vílchez, S. Making 3D-cry toxin mutants: Much more than a tool of understanding toxins mechanism of action. Toxins 2020, 12, 600. [CrossRef]

88. Tetreau, G.; Banneville, A.S.; Andreeva, E.A.; Brewster, A.S.; Hunter, M.D.; Sierra, R.G.; Teulon, J.M.; Young, I.D.; Burke, N.; Gruenewald, T.A.; et al. Serial femtosecond crystallography on in vivo-grown crystals drives elucidation of mosquitocidal Cyt1Aa bioactivation cascade. Nat. Commun. 2020, 11, 1153. [CrossRef]

89. St. Clair, N.; Shenoy, B.; Jacob, L.D.; Margolin, A.L. Cross-linked protein crystals for vaccine delivery. Proc. Natl. Acad. Sci. USA 1999, 96, 9469. [CrossRef] 
90. Yan, E.-K.; Zhao, F.-Z.; Zhang, C.-Y.; Yang, X.-Z.; Shi, M.; He, J.; Liu, Y.-L.; Liu, Y.; Hou, H.; Yin, D.-C. Seeding Protein Crystallization with Cross-Linked Protein Crystals. Cryst. Growth Des. 2018, 18, 1090-1100. [CrossRef]

91. Nair, M.S.; Lee, M.M.; Bonnegarde-Bernard, A.; Wallace, J.A.; Dean, D.H.; Ostrowski, M.C.; Burry, R.W.; Boyaka, P.N.; Chan, M.K. Cry protein crystals: A novel platform for protein delivery. PLoS ONE 2015, 10, e0127669. [CrossRef]

92. Heater, B.S.; Chan, W.S.; Lee, M.M.; Chan, M.K. Directed evolution of a genetically encoded immobilized lipase for the efficient production of biodiesel from waste cooking oil. Biotechnol. Biofuels 2019, 12, 165. [CrossRef]

93. Heater, B.S.; Yang, Z.; Lee, M.M.; Chan, M.K. In vivo enzyme entrapment in a protein crystal. J. Am. Chem. Soc. 2020, 142, 9879-9883. [CrossRef] [PubMed]

94. Yang, Z.; Heater, B.S.; Cuddington, C.T.; Palmer, A.F.; Lee, M.M.M.; Chan, M.K. Targeted myoglobin delivery as a strategy for enhancing the sensitivity of hypoxic cancer cells to radiation. iScience 2020, 23, 101158. [CrossRef] [PubMed]

95. Yang, Z.; Zheng, J.; Chan, C.-F.; Wong, I.L.K.; Heater, B.S.; Chow, L.M.C.; Lee, M.M.M.; Chan, M.K. Targeted delivery of antimicrobial peptide by Cry protein crystal to treat intramacrophage infection. Biomaterials 2019, 217, 119286. [CrossRef]

96. Chan, M.K.; Nair, M.S.; Lee, M.M. Biomaterials, Compositions, and Methods. US Patent 2010/0322977 A1, 09 December 2010.

97. Chan, M.K.; Nair, M.S. Cry Crystals for the Production of Antimicrobial Proteins. WO Patent 2013/085540, 13 June 2013.

98. Chan, M.K.; Lee, M.; Heater, B. Fusion Proteins with Improved Properties. US Patnet 2019/0185522, 20 June 2019.

99. Li, J.D.; Carroll, J.; Ellar, D.J. Crystal structure of insecticidal delta-endotoxin from Bacillus thuringiensis at $2.5 \mathrm{~A}$ resolution. Nature 1991, 353, 815-821. [CrossRef]

100. Li, J.; Henderson, R.; Carroll, J.; Ellar, D. X-ray analysis of the crystalline parasporal inclusion in Bacillus thuringiensis var. tenebrionis. J. Mol. Biol. 1988, 199, 543-544. [CrossRef]

101. Singh, S. Enzyme Catalysis and Its Role in Food Processing Industries; Springer: Singapore, 2018; pp. 143-165. [CrossRef]

102. Chapman, J.; Ismail, A.; Dinu, C. Industrial applications of enzymes: Recent advances, techniques, and outlooks. Catalysts 2018, 8, 238. [CrossRef]

103. Shah, K.; Parmar, V.K. Application of cocrystallization approach in drug development: Recent patents review. Recent Pat. Nanotechnol. 2018, 12, 143-154. [CrossRef]

104. Varshosaz, J.; Ghassami, E.; Ahmadipour, S. Crystal engineering for enhanced solubility and bioavailability of poorly soluble drugs. Curr. Pharm. Des. 2018, 24, 2473-2496. [CrossRef]

105. Sun, C.C. Cocrystallization for successful drug delivery. Expert Opin. Drug Deliv. 2013, 10, 201-213. [CrossRef] [PubMed]

106. Puhl, S.; Meinel, L.; Germershaus, O. Recent advances in crystalline and amorphous particulate protein formulations for controlled delivery. Asian J. Pharm. Sci. 2016, 11, 469-477. [CrossRef]

107. Park, H.-W.; Federici, B.A. Domain I plays an important role in the crystallization of cry3a in bacillus thuringiensis. Mol. Biotechnol. 2000, 16, 97-108. [CrossRef]

108. Lopez-Diaz, J.A.; Emiliano Canton, P.; Gill, S.S.; Soberon, M.; Bravo, A. Oligomerization is a key step in Cyt1Aa membrane insertion and toxicity but not necessary to synergize Cry11Aa toxicity in Aedes aegypti larvae. Environ. Microbiol. 2013, 15, 3030-3039. [CrossRef] [PubMed]

109. Ward, E.S.; Ellar, D.J.; Chilcott, C.N. Single amino-acid changes in the Bacillus-thuringiensis var israelensis delta-endotoxin affect the toxicity and expression of the protein. J. Mol. Biol. 1988, 202, 527-535. [CrossRef]

110. Wu, D.; Aronson, A.I. Localized mutagenesis defines regions of the Bacillus thuringiensis delta-endotoxin involved in toxicity and specificity. J. Biol. Chem. 1992, 267, 2311-2317. [CrossRef]

111. Guo, Y.; Wang, Y.; O’Donoghue, A.J.; Jiang, Z.; Carballar-Lejarazú, R.; Liang, G.; Hu, X.; Wang, R.; Xu, L.; Guan, X.; et al. Engineering of multiple trypsin/chymotrypsin sites in Cry3A to enhance its activity against Monochamus alternatus Hope larvae. Pest Manag. Sci. 2020, 76, 3117-3126. [CrossRef]

112. Munoz-Garay, C.; Rodriguez-Almazan, C.; Aguilar, J.N.; Portugal, L.; Gomez, I.; Saab-Rincon, G.; Soberon, M.; Bravo, A. Oligomerization of Cry11Aa from bacillus thuringiensis has an important role in toxicity against aedes aegypti. Appl. Environ. Microbiol. 2009, 75, 7548-7550. [CrossRef] [PubMed]

113. Perez, C.; Fernandez, L.E.; Sun, J.G.; Folch, J.L.; Gill, S.S.; Soberon, M.; Bravo, A. Bacillus thuringiensis subsp israelensis Cyt1Aa synergizes Cry11Aa toxin by functioning as a membrane-bound receptor. Proc. Natl. Acad. Sci. USA 2005, 102, 18303-18308. [CrossRef]

114. Fernandez, L.E.; Perez, C.; Segovia, L.; Rodriguez, M.H.; Gill, S.S.; Bravo, A.; Soberon, M. Cry11Aa toxin from Bacillus thuringiensis binds its receptor in Aedes aegypti mosquito larvae through loop alpha-8 of domain II. FEBS Lett. 2005, 579, 3508-3514. [CrossRef] [PubMed]

115. Likitvivatanavong, S.; Aimanova, K.G.; Gill, S.S. Loop residues of the receptor binding domain of Bacillus thuringiensis Cry11Ba toxin are important for mosquitocidal activity. FEBS Lett. 2009, 583, 2021-2030. [CrossRef]

116. McPherson, A.; Gavira, J.A. Introduction to protein crystallization. Acta Crystallogr. Sect. F Struct. Biol. Commun. 2013, 70, 2-20. [CrossRef]

117. Strandberg, B. 50 years of protein structure analysis-Chapter 1: Building the ground for the first two protein structures: Myoglobin and haemoglobin. J. Mol. Biol. 2009, 392, 2-10. [CrossRef]

118. Garman, E.F.; Weik, M. Radiation damage in macromolecular crystallography. Methods Mol. Biol. 2017, 1607, 467-489. [CrossRef]

119. Holton, J.M.; Frankel, K.A. The minimum crystal size needed for a complete diffraction data set. Acta Crystallogr. Sect. D Biol. Crystallogr. 2010, 66, 393-408. [CrossRef] [PubMed] 
120. de la Mora, E.; Coquelle, N.; Bury, C.S.; Rosenthal, M.; Holton, J.M.; Carmichael, I.; Garman, E.F.; Burghammer, M.; Colletier, J.P.; Weik, M. Radiation damage and dose limits in serial synchrotron crystallography at cryo- and room temperatures. Proc. Natl. Acad. Sci. USA 2020, 117, 4142-4151. [CrossRef] [PubMed]

121. Neutze, R.; Wouts, R.; van der Spoel, D.; Weckert, E.; Hadju, J. Potential for biomolecular imaging with femtosecond X-ray pulses. Nature 2000, 406, 752-757. [CrossRef]

122. Sauter, N.K. XFEL diffraction: Developing processing methods to optimize data quality. J. Synchrotron Radiat. 2015, 22, 239-248. [CrossRef]

123. Schlichting, I. Serial femtosecond crystallography: The first five years. IUCrJ 2015, 2, 246-255. [CrossRef]

124. Koopmann, R.; Cupelli, K.; Redecke, L.; Nass, K.; Deponte, D.P.; White, T.A.; Stellato, F.; Rehders, D.; Liang, M.; Andreasson, J.; et al. In vivo protein crystallization opens new routes in structural biology. Nat. Methods 2012, 9, 259-262. [CrossRef] [PubMed]

125. Redecke, L.; Nass, K.; DePonte, D.P.; White, T.A.; Rehders, D.; Barty, A.; Stellato, F.; Liang, M.; Barends, T.R.; Boutet, S.; et al. Natively inhibited Trypanosoma brucei cathepsin B structure determined by using an X-ray laser. Science 2013, 339, 227-230. [CrossRef]

126. Nass, K.; Redecke, L.; Perbandt, M.; Yefanov, O.; Klinge, M.; Koopmann, R.; Stellato, F.; Gabdulkhakov, A.; Schönherr, R.; Rehders, D.; et al. In cellulo crystallization of Trypanosoma brucei IMP dehydrogenase enables the identification of genuine co-factors. Nat. Commun. 2020, 11, 620. [CrossRef]

127. Tang, Y.; Saul, J.; Nagaratnam, N.; Martin-Garcia, J.M.; Fromme, P.; Qiu, J.; LaBaer, J. Construction of gateway-compatible baculovirus expression vectors for high-throughput protein expression and in vivo microcrystal screening. Sci. Rep. 2020, 10, 13323. [CrossRef]

128. Crickmore, N.; Berry, C.; Panneerselvam, S.; Mishra, R.; Connor, T.R.; Bonning, B.C. A structure-based nomenclature for Bacillus thuringiensis and other bacteria-derived pesticidal proteins. J. Invertebr. Pathol. 2020, 107438. [CrossRef] [PubMed]

129. Xu, C.; Wang, B.C.; Yu, Z.; Sun, M. Structural insights into Bacillus thuringiensis Cry, Cyt and parasporin toxins. Toxins 2014, 6 , 2732-2770. [CrossRef]

130. Colletier, J.P.; Schiro, G.; Weik, M. Time-resolved serial femtosecond crystallography, towards molecular movies of biomolecules in action. In X-ray Free Electron Lasers-A Revolution in Structural Biology; Boutet, S., Fromme, P., Hunter, M.S., Eds.; Springer International Publishing: Berlin, Germany, 2018; p. 479. [CrossRef]

131. Konold, P.E.; Arik, E.; Weißenborn, J.; Arents, J.C.; Hellingwerf, K.J.; van Stokkum, I.H.M.; Kennis, J.T.M.; Groot, M.L. Confinement in crystal lattice alters entire photocycle pathway of the Photoactive Yellow Protein. Nat. Commun. 2020, 11, 165. [CrossRef] [PubMed]

132. Cho, A. Rebirth of leading European facility promises revolutionary advances in X-ray science. Science News, 15 July 2020. [CrossRef] 